\title{
RANCANG BANGUN ALAT PENGAMAN KENDARAAN BERMOTOR MENGGUNAKAN MEDIA TRANSMISI BLUETOOTH BERBASIS ANDROID DENGAN BAHASA C
}

\author{
Kapti \\ STMIK Bina Patria Magelang \\ Program Studi Teknik Informatika \\ e-mail: tensmart18@Gmail.com
}

\begin{abstract}
Abstrak
Penelitian ini bertujuan dapat membangun sistem pengaman kendaraan bermotor yang terhubung dengan gadget android melalui transmisi Bluetooth dan mampu menerapkan sistem elektronik IC ATMega 328 yang terdapat pada Arduino Nano. Alat ini dibuat karena banyaknya kasus pencurian kendaraan bermotor yang disebabkan karena kelalaian pemiliknya. Metode yang digunakan adalah metode penelitian eksperimen (experimental research) [1] mendefinisikan eksperimen sebagai suatu penelitian yang dengan sengaja peneliti melakukan manipulasi terhadap satu atau lebih variabel dengan suatu cara tertentu sehingga berpengaruh pada satu atau lebih variabel lain yang di ukur. Hasil penelitian ini adalah terciptanya alat pengaman kendaraan dengan media sensor bluetooth berbasis android dengan bahasa $C$ menggunakan mikrokontroler Arduino Nano ATMega328, alat ini telah diuji dan dapat membantu mengamankan kendaraan bermotor dengan menggunakan smartphone android
\end{abstract}

Kata kunci: ATMega 328, Arduino Nano, Bluetooth, mikrokontroler

\section{Pendahuluan}

Perkembangan alat transportasi di Indonesia mengalami kemajuan yang sangat pesat, hal tersebut di buktikan bahwa rata-rata setiap keluarga di Indonesia memiliki kendaraan pribadi, dengan data pada tahun 2015 bahwa jumlah kendaraan roda dua sesuai data dari badan pusat statistik sejumlah 98.881.267 kendaraan, dan tahun berikutnya yakni tahun 2016 mengalami peningkatan menjadi 105.150.082 [2], dari data statistik diatas dapat juga digunakan sebagai perhitungan seberapa tinggi intensitas daya beli masyarakat dan tingkat ekonomi suatu bangsa.

Perkembangan dalam alat transportasi tersebut pasti menimbulkan dampak bagi masyarakat, dampak yang muncul berupa dampak positif dan negatif, dampak postif dari perkembangan alat transportasi di Indonesia adalah kemudahan bagi masyarakat dalam menjalankan aktivitas seharihari baik untuk keperluan pribadi maupun umum seperti transportasi umum bagi masyarakat maupun transportasi barang, dan dampak negatifnya adalah tindak kejahatan pencurian kendaraan bermotor semakin marak, data dari kepolisian daerah Jawa Tengah menyatakan bahwa pada tahun 2016 terdapat 240 kasus tindak pidana pencurian sepeda motor sedangkan tahun 2017 terdapat 321 kasus tindak pidana pencurian kendaraan sepeda motor [3], meskipun dalam hal ini setiap produsen kendaraan bermotor sudah membuat sistem keamanan sendiri, tetapi tindak kejahatan pencurian kendaraan bermotor belum mampu di hindari.

Tindak pencurian kendaran bermotor, biasanya terjadi akibat kelalaian dari pemilik kendaraan yang kurang berhati-hati dan ceroboh dalam mengamankan kendaraan atau peralatan lainnya, dalam salah satu contoh, pemilik kendaraan terkadang lalai untuk mengambil kunci kendaraan dan masih melekat di kendaraan, sehingga orang yang mempunyai niat jahat, mudah untuk melakukan tindak kejahatannya.

Dalam beberapa kasus, orang-orang butuh tindakan pencegahan agar kendaraan yang dimiliki 
tidak menjadi sasaran tindak kejahatan. Salah satu caranya adalah dengan mengamankan pengaman pada kendaraan. Sistem keamanan kendaraan akan dirancang dengan sensor pengaman.Sensor pengaman pada kendaraan tersebut dapat disinkronkan dengan perangkat android yang sudah menjadi bagian hidup masyarakat saat ini. Perangkat android digunakan sebagai kontrol kendaraan, sehingga pengaman yang digunakan akan berbeda dengan apa yang produsen kendaraan biasa gunakan. Maka dari itu permasalahan ini menjadi kesempatan bagi para ilmuwan untuk mengembangkan purwarupa alat pengaman kendaraan yang tersinkron dengan gadget

\section{LANDASANTEORI}

A. Teori Sistem Pengamanan Kendaraan Bermotor

Pengertian dari Pengamanan kendaraan Bermotor adalah sebuah alat yang mampu mengontrol akses kendaraan dalam jarak tertentu[4]. Alat ini sebagai pengaman dari tindak kejahatan pencurian kendaraan bermotor yang bekerja apabila seseorang memaksa untuk mengambil kendali dari sebuah kendaraan yang terkunci oleh sandi.

B. Mikrokontroler

Mikrokontroler atau pengendali mikro adalah sebuah komputer kecil (Special Purpose Computers) di dalam sebuah IC/chip. Dalam sebuah IC/Chip mikrokontroler terdapat CPU, memori, timer, saluran komunikasi serial dan paralel, port input/output, ADC, dll [5]

[6],mikrokontroler dapat diprogram menggunakan komputer sehingga rangkaian elektroniknya dapat membaca input data lalu memproses dan mengeluarkan outputnya sesuai perintah program yang diberikan. Salah satu jenis mikrokontroler yang terbaru saat ini adalah mikrokontroler Arduino [5]

C. Bahasa C/ C++

Tahun 1978, Brian W. Kerninghan \& Dennis M. Ritchie dari AT \& $\mathrm{T}$ Laboratories mengembangkan bahasa $\mathrm{B}$ menjadi bahasa $\mathrm{C}$. Bahasa B yang diciptakan oleh Ken Thompson sebenarnya merupakan pengembangan dari bahasa BCPL ( Basic Combined Programming
Language ) yang diciptakan oleh Martin Richard[7].

Dalam perkembangannya, bahasa $\mathrm{C}$ menjadi bahasa paling populer diantara bahasa lainnya, seperti PASCAL, BASIC, FORTRAN.

D. Pengertian Arduino

Menurut Mike Schmidt, Arduino merupakan mikrokontroler yang memamng dirancang untuk bisa digunakan dengan mudah oleh para seniman dan desainer (yang memang bukan orang teknik). Tanpa mengetahui bahasa pemrograman, arduino bisa digunakan untuk menghasilkan karya yang canggih [8]Berikut ini adalah gambar hardware arduino uno.

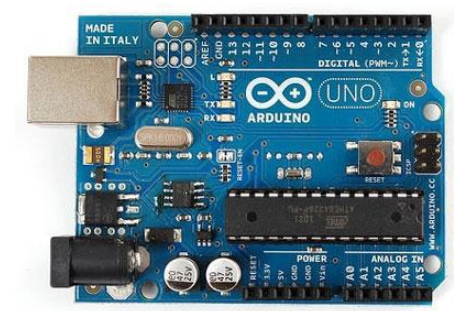

Gambar 1. Board Arduino Uno

\section{E. Bahasa Pemrograman Android}

Android adalah sistem operasi berbasis Linux yang dirancang untuk perangkat bergerak layar sentuh seperti telepon pintar dan komputer tablet. Android awalnya dikembangkan oleh Android, Inc., [9]

F. Bluetooth Module HC-05

Bluetooth Module HC-05 merupakan module komunikasi nirkabel pada frekuensi $2.4 \mathrm{GHz}$ dengan pilihan koneksi bisa sebagai slave, ataupun sebagai master. Sangat mudah digunakan dengan mikrokontroler untuk membuat aplikasi wireless. Interface yang digunakan adalah serial RXD, TXD, VCC dan GND. Built in LED sebagai indikator koneksi bluetooth[10].

\section{METODE}

Metode penelitian yang dilakukan adalah metode penelitian eksperimen (experimental research)[1].Penelitian eksperimen merupakan suatu penelitian yang menjawab pertanyaan "jika kita melakukan sesuatu pada kondisi yang dikontrol secara ketat maka apakah yang akan 
terjadi?". Untuk mengetahui apakah ada perubahan atau tidak pada suatu keadaan yang di control secara ketat maka kita memerlukan perlakuan (treatment) pada kondisi tersebut dan hal inilah yang dilakukan pada penelitian eksperimen. Sehingga penelitian eksperimen dapat dikatakan sebagai metode penelitian yang digunakan untuk mencari pengaruh perlakuan tertentu terhadap yang lain dalam kondisi yang terkendalikan. Metode eksperimen adalah metode penelitian yang digunakan utuk mencari pengaruh perlakuan tertentu terhadap yang lain dalam kondisi yang terkendalikan[11]

\section{HASIL}

Analisis Kebutuhan Sistem

a. Kebutuhan Fungsional

Kebutuhan fungsional disini berupa kebutuhan yang berisi proses-proses apa saja yang nantinya dilakukan oleh alat pengaman. Kebutuhan fungsional juga berisi informasiinformasi apa saja yang harus ada dan dihasilkan oleh alat pengaman[8]. Berikut kebutuhan fungsional yang terdapat pada alat pengaman yang di bangun:

1) Sistem mampu melakukan interaksi kontrol dengan mikrokontroler.

2) Sinyal bluetooth dapat terdeteksi oleh sistem remote.

3) Sistem mematikan alarm (klakson) apabila kendaraan bermotor dihidupkan paksa oleh orang lain dan alarm berbunyi.

4) Sistem dapat menampilkan pemberitahuan saat terjadi kesalahan koneksi sinyal bluetooth.

5) Sistem mampu menyalakan dan mematikan koneksi bluetooth.

b. Kebutuhan Nonfungsional

Analisa kebutuhan non fungsional dilakukan untuk mengetahui spesifikasi kebutuhan perancangan alat pengaman. Spesifikasi kebutuhan melibatkan analisi perangkat keras, analisa perangkat lunak dan analisa pengguna.

1) Analisa Perangkat Keras

Dalam membuat alat pengaman kendaraan ini, perangkat keras yang digunakan adalah sebagai berikut: a) Seperangkat Komputer Desktop / Laptop AMD E-450 APU withRadeon(tm) HD Graphics 1.65 $\mathrm{GHz}$

b) Arduino Nano dengan IC ATMega328[12]

c) Bluetooth modul HC-05

d) Handphone android Xiaomi Redmi 2

e) Kabel USB

2) Analisa Perangkat Lunak Perangkat lunak yang digunakan dalam perancangan alat pengaman kendaraan ini, antara lain:

a) Eclipse IDE / Android Studio IDE

b) Arduino IDE

c) Bahasa $\mathrm{C} / \mathrm{C}++$

3) Analisa Pengguna

Pengguna dari alat pengaman kendaraan ini adalah masyarakat umum dan para penggagas IT yang ingin mengembangkan alat ini menjadi lebih baik.

Perancangan Kebutuhan Sistem

a. Perancangan Kebutuhan Pengguna. Dalam kesehariannya pengguna dalam menggunakan kendaraan sudah dibekali dengan sistem keamanan konvensional yang ada di kendaraan bermotor pribadinya, namun sistem konvensional yang ada saat ini kurang mampu untuk mengurangi tindak pencurian kendaraan bermotor dikarenakan sistem keamanan konvensional sudah banyak diketahui oleh para pelaku tindak kriminal pencurian kendaraan bermotor.

Para pemilik kendaraan bermotor membutuhkan informasi secepat mungkin apabila tindak kejahatan pencurian yang terjadi pada kendaraan yang dimilikinya.

b. Perancangan Sistem

Dalam menyusun rangkaian mikrokontroler dibutuhkan beberapa komponen elektronika, sebagai berikut:

1. 1 buah Arduino Nano ATMega328

2. 1 buah Relay modul $5 \mathrm{~V}$

3. 2 buah Resistor $330 \mathrm{Ohm}$

4. 2 buah Switch

5. 1 buah Bluetooth Module HC-05 


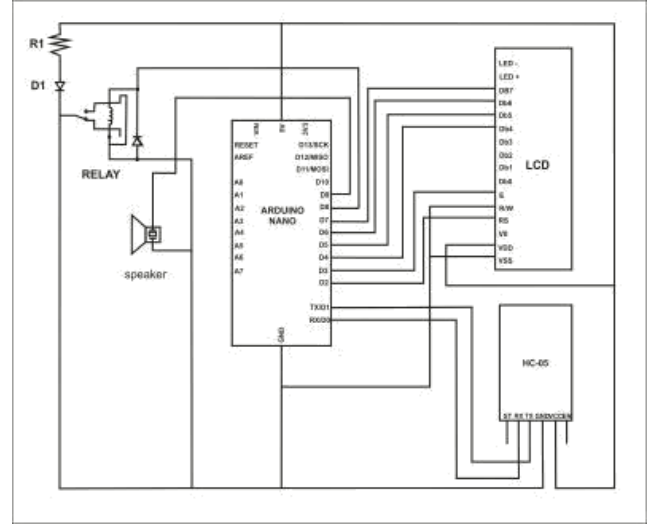

Gambar 2. Skema Rancangan Perangkat Pengaman Kendaraan Bermotor

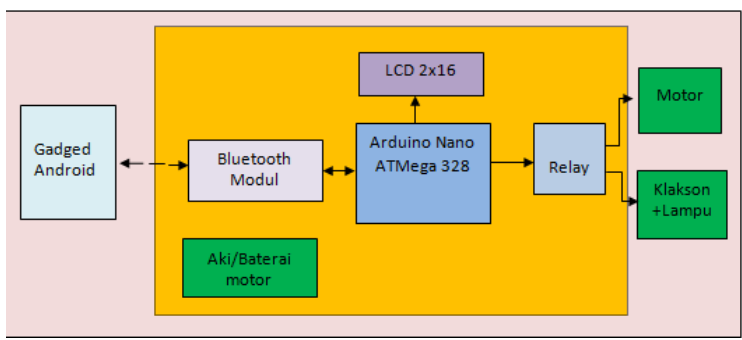

Gambar 3. Diagram Blok Rancangan Perangkat Pengaman Kendaraan Bermotor

c. Implementasi Tampilan Remote di Android

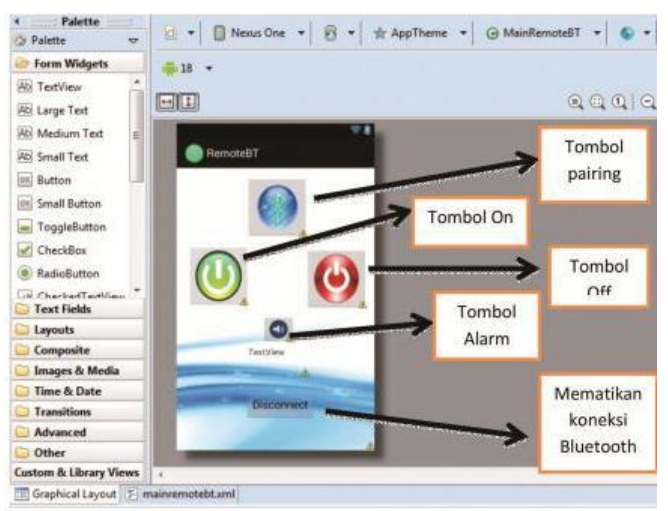

Gambar 3. Tampilan Remote d. Implementasi Perangkat Purwaarupa

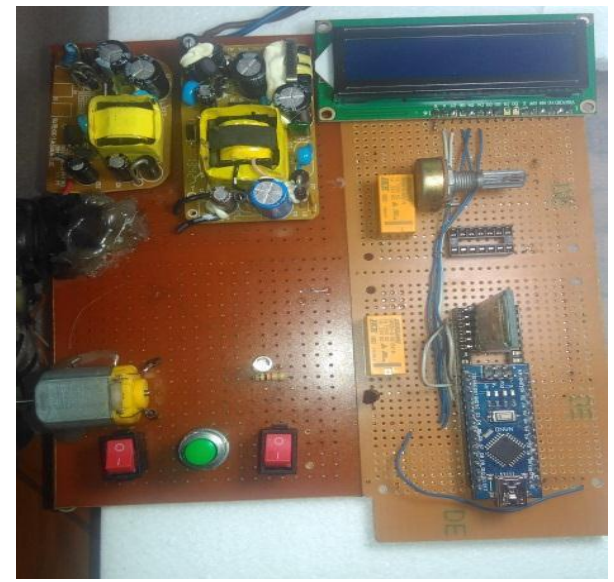

Gambar 5. Tampilan Perangkat

e. Implementasi Perangkat Purwarupa

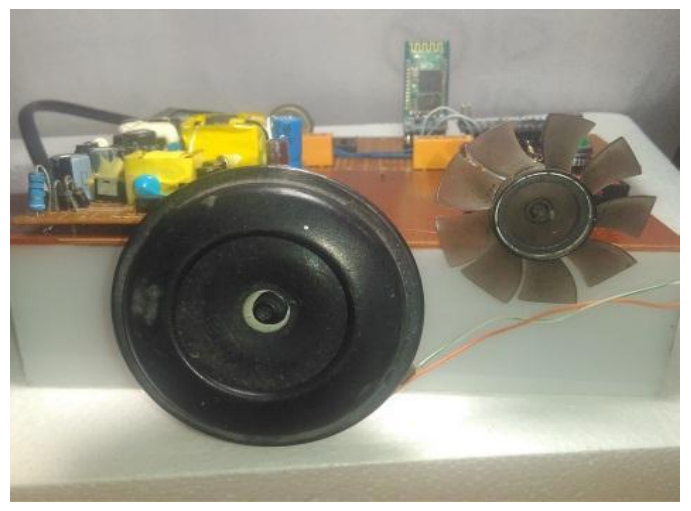

\section{KESIMPULAN}

Bagian Setelah dirancang dan dibuat alat pengaman kendaraan bermotor dengan media bluetooth berbasis android, maka dapat disimpulkan sebagai berikut :

a. Sistem mampu mengamankan kendaraan lebih aman dari kunci konvensional.

b. Sistem mampu memberikan respon balik kepada pemilik kendaraan.

c. Mengurangi tingkat tindak kejahatan pencurian kendaraan bermotor yang terjadi akibat kunci kontak konvensional.

Penggunaan remote kontrol android pada kendaraan bermotor menjadikan kendaraan dapat dikendalikan dari jarak jauh, sehingga berakibat efisiensi pada saat penghidupan mesin bermotor. 


\section{Daftar Pustaka}

[1] Arboleda, "Metode Penelitian Eksperimental," 2015. [Online]. Available: https://www.eurekapendidikan.com/2015/11/met ode-penelitian-eksperimen.html.

[2] BPS, "Perkembangan Jumlah kendaraan Bermotor Menurut Jenis 1949-2016,” 2016. [Online]. Available: https://www.bps.go.id/linkTableDinamis/view/id $/ 1133$.

[3] nasional.republika.co.id, "Kasus Curanmor Jawa Tengah," nasional.republika.co.id, Jawa Tengah, 2017.

[4] Ardiansyah, B. Irawan, and T. Rismawan, "Rancang bangun sistem keamanan kendaraan bermotor dengan sms gateway berbasis mikrokontroler dan android," J. Coding Sist. Komput. Univ. Tanjungpura, vol. 3, no. 1, pp. 42-51, 2015.

[5] H. Andrianto, Pemrograman Mikrokontroler AVR Atmega 16 mengunakan bahasa $C+C D$. INFORMATIKA, 2013.

[6] Y. M. Dinata, Arduino itu Pintar. Elex Media Komputindo, 2016.

[7] D. Krupke, F. Wasserfall, N. Hendrich, and J. Zhang, "Printable modular robot: an application of rapid prototyping for flexible robot design," Ind. Robot An Int. J., vol. 42, no. 2, pp. 149$155,2015$.

[8] W. Komputer, Pemrograman Android Dengan APP Inventor. Andi Publisher, 2013.

[9] J. E. Istiyanto, Pengantar Elektronika dan Instrumentasi Pendekatan Project Arduino dan Android. Yogyakarta: CV.Andi Offset, 2014.

[10] J.-F. Tu, "A contactless door lock controlled by portable devices," Eng. Comput., vol. 33, no. 6, pp. 1631-1641, 2016.

[11] S. R. Manalu, J. Moniaga, D. A. Hadipurnawan, and F. Sahidi, "OBD-II and raspberry Pi technology to diagnose car's machine current condition: study literature," Libr. Hi Tech News, vol. 34 , no. 10, pp. 15-21, 2017.

[12] B. Wong, G. T. S. Ho, and E. Tsui, "Development of an intelligent e-healthcare system for the domestic care industry," Ind. Manag. Data Syst., vol. 117, no. 7, pp. 14261445, 2017. 